\title{
Foldamer-Catalyzed Macrocyclizations
}<smiles>O=CCc1cc(O)cc(OC=O)c1</smiles>

$$
\begin{gathered}
\begin{array}{c}
\text { catalyst (10 mol\%) } \\
\mathrm{E}_{3} \mathrm{~N}(1 \text { equiv) }
\end{array} \\
\mathrm{MeCH}_{2} \mathrm{CO}_{2} \mathrm{H} \text { (1 equiv) } \\
\begin{array}{c}
i-\mathrm{PrOH}-\mathrm{H}_{2} \mathrm{O}(96: 4) \\
37^{\circ} \mathrm{C}, 24 \mathrm{~h}, 1 \mathrm{mM} \text { dial }
\end{array}
\end{gathered}
$$

$\stackrel{\mathrm{MeCH}_{2} \mathrm{CO}_{2} \mathrm{H} \text { (1 equiv) }}{\longrightarrow}$ macrocycles 1-4

$\mathrm{n}=4,5,6,7$
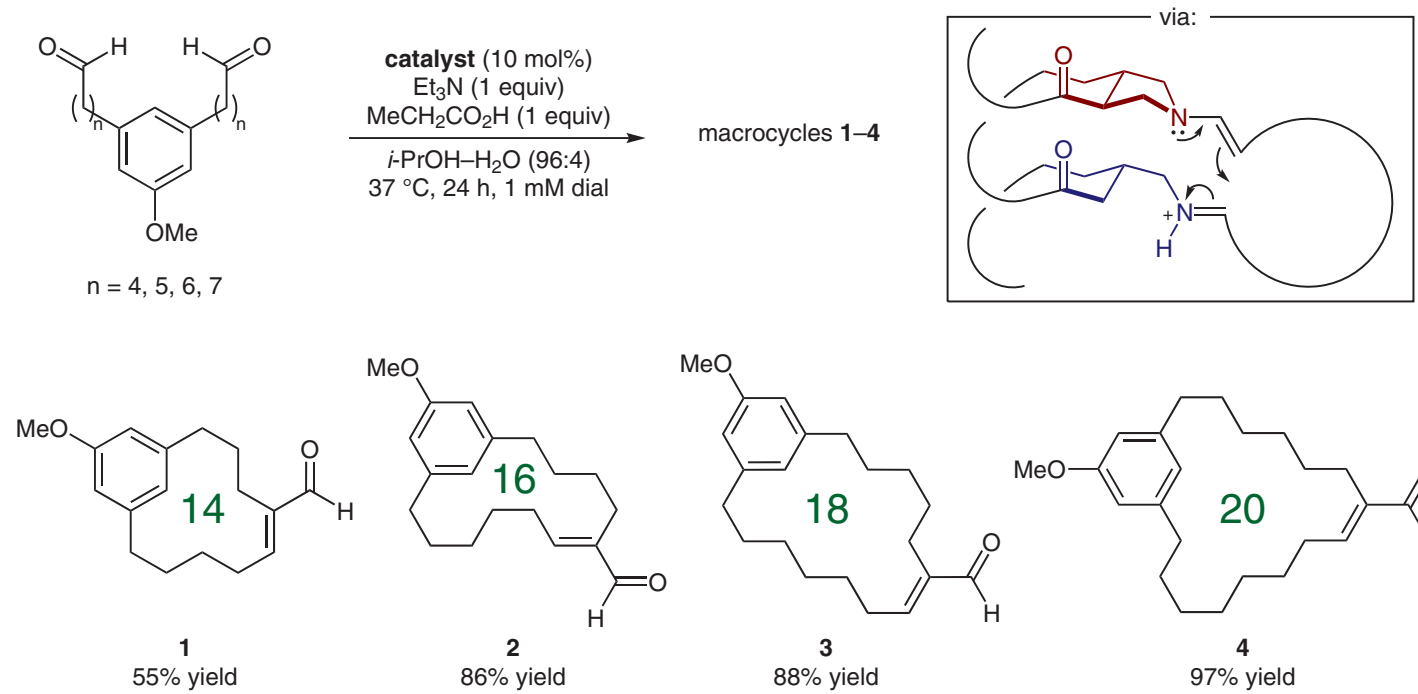

3

$88 \%$ yield

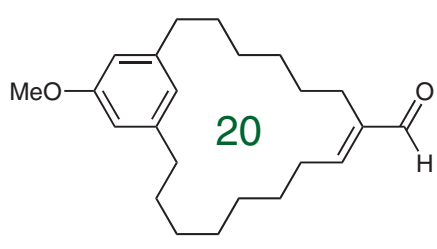

4

$97 \%$ yield<smiles>CC(=O)NC(C)(C)C(C)=O</smiles><smiles>NC(=O)C1C2CNC1N2</smiles><smiles>CC(=O)C1=CC2CNC1C2</smiles><smiles>CC(=O)NC(C)(C)C(C)=O</smiles>

catalys<smiles>NCCC(=O)NC1CCC2CC1CC2C(=O)NC(Cc1ccc(O)cc1)C(N)=O</smiles>

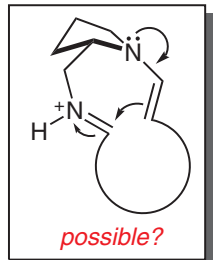

Significance: Gellman and co-workers report a foldamer-catalyzed macrocyclization of dialdehydes to form 14- to 22-membered rings in good to excellent yields. The reaction proceeds through a highly selective intramolecular aldol condensation and generally outcompetes deleterious intermolecular reactions, despite the high entropic barriers associated with large-ring closures. Notably, the authors employed this method as the key step in a total synthesis of robustol, a natural product containing a 22-membered ring.
Comment: A distinct relationship between the structure of the $\alpha / \beta$-peptide foldamer and the efficiency of macrocycle formation was observed and highlights the importance of the helical conformation of the oligomer, as well as the three-dimensional alignment of the participating primary and secondary amine groups. Along these lines, the authors performed a key control experiment that demonstrated the inefficiency of pyrrolidine and butylamine as co-catalysts for the macrocyclization. However, given the entropic advantage provided by the tethered nature of the amine functionalities in the employed oligomer, one does wonder about the catalytic behavior of simple small-molecule diamines, for example, 2-(aminomethyl)pyrrolidine, which might enable a similar Mannich-type mechanism, as well as potentially reduce the entropic cost of ring closure. 